\title{
SOLVENCY II: THE IMPLICATIONS OF ITS APPLICATION ON THE ROMANIAN INSURANCE MARKET
}

\author{
Ioan Marius Ciotină ${ }^{1}$ \\ "Alexandru Ioan Cuza" University of Iaşi \\ ianis20032002@yahoo.com
}

\begin{abstract}
Solvency II is a European directive whose purpose is to update the regulations concerning the insurance market. This is more than a set of rules on the solvency of insurance companies and is a comprehensive set of rules on the entire insurance market from solvency, liquidity and information asymmetry between actors to an insurance transaction. The aim of this article is to present the implications of applying Solvency II in Romania and the changes that will occur on the insurance market. We also present the advantages of moving from the current regulation, namely Solvency I to Solvency II Directive, both by comparative analysis between both directly and through analysis of test results QIS5 applied in Romania. We will also show the current situation of the insurance market by emphasizing evolution and the solvency margin of solvency for the last six years from 2007, the year before the financial crisis and in 2012, the year for which there last available data.
\end{abstract}

\section{Keywords}

Solvency II; insurance market; risk insurance

\section{JEL Classification}

G22

\section{Introduction}

The purpose of the Solvency II project is to update the regulation framework concerning the European insurance market.

In this paper we present the framework that led to the need to develop this directive and underlying structure. We will also show the implications of its adoption in the insurance market in Romania and changes. Next we show test results of QIS5 in Romania and the solvency margin of solvency in the last six years under the regulation applied to the Solvency I.

\section{Considerations Concerning the Structure of Solvency II}

One of the main objectives of the European Union is to achieve a truly single market. The first rules on insurance date back since the 1970's and, subsequently, updates have been applied on the convergent markets (Eling et al., 2007).

Since these regulations have become obsolete at the end of the 1990's, a decision was taken to revise them, and in parallel to develop the Basel II Regulation, which applies in the banking system. The European Parliament had a two-staged approach, respectively Solvency I (which became applicable in 2004), which updated the thresholds (existent since 1970) regarding the necessary capital for insuring solvency,

\footnotetext{
${ }^{1}$ PhD student "Alexandru loan Cuza" University of laşi, Faculty of Economics and Business Administration
} 
without changing the computing method, and Solvency II, a substantial reform of the supervision structures and practices. Solvency is the ability of a company to stand payments that may occur, irrespective of their value.

In parallel with the process of drawing Solvency II, other evaluation frameworks have been created concerning capital and solvency, in countries such as the Great Britain, Switzerland, or Holland. Also, the International Association of Insurance Supervisors (IAIS) started working in the direction of insuring the convergence of the various analysis systems of solvency in the insurance field. Among these, Solvency II is the most important, as this regulation will apply to the entire European insurance market. Solvency II is based on three pillars, which are also present in Basel II. The first pillar focuses on the financial aspects, such as the value of capital in a balance sheet, the payment obligations and assets of a company. Moreover, Pillar I includes two capital indicators, respectively the Solvency Capital Requirement (SCR), which can be computed either through a standard approach or using the internal models of insurance companies. The standard approach of the SCR indicator includes a single formula, which needs to be applied by all insurance companies, irrespective of their size, portfolio, or geographical location. Nevertheless, the insurers may opt for designing their own computing model, which would better fit their risk profile, but this would have to be approved by the supervision entities. The accepted value of SCR is $99.5 \%$.

The second indicator in the Solvency II directive is the Minimum Capital Requirement (MCR). Not insuring the MCR triggers the intervention of the supervision entities (Solvency II, art. 136), which leads to the conclusion that the MCR indicator refers to a minimum capital level that guarantees a certain safety for the insurers. A similar philosophy is applied by Basel II (Basel Committee on Banking Supervision, 2004), as a stimulus for companies to improve their risk policies. Up until now, the most significant progresses have been achieved in the regulation of Pillar I.

Pillar II and Pillar III refer to diminishing the asymmetry of the information between the agents involved. The reason for regulating an insurance market is often related to its imperfections, such as the agency issue and obtaining information, which can be rather costly (Klein, 1995). The agency issue refers to the information asymmetry between the owners or managers of the insurance companies, on the one hand, and the owners of insurance policies on the other. This asymmetry can be solved by collecting and distributing more information, which implies a certain cost. It is generally accepted that a regulation in the field of insurance should be designed so as to increase the market competitiveness as much as possible. One of the elements of and effective and competitive market is the fact that all the participants who operate on the respective market have access to relevant information. In this sense, one of the regulations aims at increasing the discipline on the market, requiring the reporting of information in order to efficiently manage the market risks.

Professor Jacques Sijben concludes that the so-called Early Intervention Procedure and the solving process, which is the basis of Pillars II and III, is much more stable and effective than the capital demands.

\section{Solvency II from the Perspective of its Application in Romania}

After several delays, the application of Solvency II in Romania will become compulsory starting with 2016, so that, beginning with 2015, insurance companies will have to report to the Financial Supervision Authority concerning the situation of the implementation of the new norms on solvency and capital. The new rules, much stricter than those currently applicable, will generate important movements on the market. 
The most significant modification brought by Solvency II compared to the present regulations that apply on the Romanian insurance market, respectively the Solvency I directive, is considering six new risk categories in determining the solvency of insurance companies. For now, this indicator is computed according to the exposition of the insurer and to the estimated damages, but after the application of Solvency II, the analysis will also include the subscription, liquidity, concentration, market, credit, and strategic risks. Following the implementation of the Solvency II directive, solvency will become the most important indicator in evaluating an insurance company. At present, this evaluation is done according to the volume of the gross commissions subscribed, that is, to the volume of insurance sales.

By introducing the market and strategic risk in computing the solvency of insurance companies, such a company will also be evaluated according to the country where it performs its activity. Thus, two companies in different countries, having the same portfolio of products and with the same volume of sales, will be evaluated differently, according to the business environment in each country.

Concentration risk refers to focusing the entire products portfolio only on specific types of insurance, such as car insurance. Subscription risk is related to the type of customers of an insurance firm and to their degree of exposure to risk - the higher their risk, the higher the risk taken by the insurance company.

Romania is one of the most exposed countries in Europe to catastrophes, and a first step in harshening the conditions concerning solvency was taken in 2012, when new rules were introduced concerning reinsurance, but only for calamity insurance. With the implementation of Solvency II, additional conditions will apply concerning the necessary capital for insurance companies, in order to insure enough solvency, which will affect the entire insurance market.

Another modification refers to the type of model used to compute solvency. If, at present, the approach based on historical data is the only one used, Solvency II introduces the model based on historical data as well as on the risk factors that may have effects, such as natural disasters.

In what concerns the asset portfolio, Solvency II recommends investing only in financial instruments implying risks that are easy to evaluate, identify, and manage. It also suggests diversifying the asset portfolio in order to reduce risk.

At a European level, the Supervising European Committee from Insurance and Occupational Pensions (CEIOPS) organized the fifth quantitative impact study, called QIS5. Of the 3,600 insurance companies in Europe, 65\% participated in the QIS5test. In Romania, 18 insurers took part in QIS5, owing approximately 93.9\% of the gross commissions subscribed for life insurance and $79.8 \%$ for general insurance. The results of the QIS5 test for Romania can be synthesized as follows:

- Considering the transition from the present solvency regime to Solvency II, which at a global level may be characterized by an increase in capital requirements, a decrease in the value of the technical reserves and a raise in the need for eligible costs, we can notice that the financial position of the insurance sector in Romania remains stable. The necessary capital surplus, resulted according to the technical specification of the QIS5 test, is only $17.47 \%$ of the current need;

- According to the quantitative results and observations obtained within the QIS5 test, we can draw the conclusion that the design of Solvency II was extremely sustained. Nevertheless, in order to insure compatibility, the evaluation methodologies for the technical reserves (defining the limits for insurance contracts, computing the risk margin) and for the delayed taxes, additional analyses were required;

- QIS tested if the system is correctly calibrated, that is, if the value of $99.5 \%$ for SCR is correct for a period of one year. Generally, although the results proved 
it, some areas have been identified where additional calibration is required, such as: the catastrophe risk, commissions and technical reserves for general insurance;

- The high participation ratio of the insurance companies to QIS5 gives a positive message on the fact that the insurance sector is preparing to apply the new supervision system. Although the insurers' QIS5 reports show that certain aspects should be improved (data quality, IT systems, the human resource training system), there were several positive signals, and all the participants stated that they will be ready upon the entrance into force of the new supervision system.

The application of Solvency II brings a series of benefits both for the insurer and for the insured.

For the insurer, we list benefits such as: a drop in the losses suffered by the insured, permission to use own evaluation models, fewer costs and increased flexibility, strict supervision that facilitates the very fast adaptation of the capital to the requirements; for the insurer, we can mention: a drop in the bankruptcy risk for the insurer, a diminution of insurance commissions, a diversification of the products, as well as their correlation to personal needs (Novac \& Badea, 2008).

\section{Characterization of the Solvency of Insurance Companies for the Period of the Pre-Adoption of Solvency II}

In order to stress the changes brought by the introduction of Solvency, II we must present the current solvency status of insurance companies, under the regime of Solvency I. The most important indicators used are the solvency margin and the degree of solvency.

The available solvency margin is an indicator computed as the difference between the value of the assets and the value of the liabilities of a company, and it is in fact the shareholder's equity of the insurer. This indicator has constantly increased since 2007 until 2011, when we witnessed a drop, which persisted in 2012.

Looking at the two insurance categories, the tendency was similar, with only one exception: in 2012, the solvency margin for life insurance increased by 33,138,346 lei, respectively by $3.22 \%$.

Table 1 present market developments related to the solvency margin of Romania in the period 2007-2012.

Table 1 Evolution of the solvency margin available for the Romanian insurance market, for the period 2007-2012

\begin{tabular}{|c|c|c|c|c|c|c|}
\hline $\begin{array}{c}\text { Available } \\
\text { solvency margin } \\
\text { (lei) }\end{array}$ & $\mathbf{2 0 0 7}$ & $\mathbf{2 0 0 8}$ & $\mathbf{2 0 0 9}$ & $\mathbf{2 0 1 0}$ & $\mathbf{2 0 1 1}$ & $\mathbf{2 0 1 2}$ \\
\hline Life insurance & 666.682 .358 & 944.393 .619 & 1.199 .193 .246 & 1.219 .431 .465 & 1.028 .915 .044 & 1.062 .053 .390 \\
\hline $\begin{array}{c}\text { General } \\
\text { insurance }\end{array}$ & 1.615 .625 .237 & 1.856 .450 .935 & 2.012 .033 .024 & 2.125 .511 .889 & 2.038 .318 .791 & 1.939 .918 .788 \\
\hline
\end{tabular}

Source: www.csa-isc.ro

Besides the available solvency margin, another important indicator is the minimum solvency margin, which is the minimum capital that an insurer must own at all times; if its value is lower, it means an impossibility to pay the obligations to the insured. Dividing the available solvency margin by the minimum solvency margin, we obtain the degree of solvency, which must be higher than one in order to have sufficient solvency for making any required payments. This indicator had an oscillating 
evolution for the analyzed period. For life insurance, the degree of solvency dropped in 2008 to 3.64, and in 2009 it reached 4.46. Two drop years followed, respectively to 4.29 in 2010, 3.93 in 2011, and 3.94 in 2012. For the six analyzed year, the degree of solvency of general insurance dropped from 2.38 for 2007 to 1.97 in 2012.

These evolutions were caused by a decrease in the insurance commissions subscribed, which have dropped since the beginning of the financial crisis. Nevertheless, as the insurance commissions diminished, the paid damages went up, which made for the insurance companies to have negative results from the basic activity, resulting in lower solvency.

Table 2 presents the evolution of solvency for the insurance market in Romania between 2007 and 2012.

Table 2 Evolution of the degree of solvency of the insurance market in Romania, for the period 2007-2012

\begin{tabular}{|c|c|c|c|c|c|c|}
\hline $\begin{array}{c}\text { Degree of } \\
\text { solvency }\end{array}$ & $\mathbf{2 0 0 7}$ & $\mathbf{2 0 0 8}$ & $\mathbf{2 0 0 9}$ & $\mathbf{2 0 1 0}$ & $\mathbf{2 0 1 1}$ & $\mathbf{2 0 1 2}$ \\
\hline $\begin{array}{c}\text { Life } \\
\text { insurance }\end{array}$ & 3.85 & 3.64 & 4.46 & 4.29 & 3.93 & 3.94 \\
\hline $\begin{array}{c}\text { General } \\
\text { insurance }\end{array}$ & 2.38 & 2.14 & 2.15 & 2.21 & 2.13 & 1.97 \\
\hline
\end{tabular}

Source: www.csa-isc.ro

\section{Conclusions}

For the insurance field, the obvious effects of the crisis, besides the financial problems, consisted in higher liquidity and insolvency risks. These aspects are approached based on the principles that constitute the regulations of Solvency II. After multiple delays, Solvency II will be compulsory for the entire Romanian market and will determine numerous changes for insurance companies. Although a capital level correlated with the risk profile, a more careful supervision of the taken risks, as well as an increase in the degree of responsibility are required, the measure can also determine, in a first stage, for some insurance companies to encounter difficulties in attracting the additional capital needed. Nevertheless, de degree of meeting the QIS5 test shows that the actors on the market are aware of the benefits of the new regulation and declare themselves prepared to apply it.

\section{References}

Basel Committee on Banking Supervision (2004), International Convergence of Capital Measurement and Capital Standards: A Revised Framework, Bank for International Settlements, Basel (June).

Butaci, C. (2013), Modeling the Risk in Agreement with the Solvency II Regulations and Possible Implications on the Romanian Insurance Market, Ovidius University Annals, Economic Sciences Series, XIII (2), 548-552.

Commision of the European Communities (2008), Amended Proposal for a Directive of the European Parliament and of the Council on the taking-up and pursuit of the business of Insurance and Reinsurance (Solvency II), available at http://ec.europa.eu/internal_market/insurance/docs/solvency/proposal_en.pdf.

Eling, M., Schmeiser, H., Schmit, J. (2007), The Solvency II process: Overview and critical analysis, Risk Management and Insurance Review, 10, 69-85. 
European Insurance and Occupational Pensions Authority, Public consultation on the Set 1 of the Solvency II Guidelines, available at https://eiopa.europa.eu/ consultations/consultation-papers/index.html.

Klein, R. W. (1995), Insurance regulation in transition, Journal of Risk and Insurance, 62, 363-404.

Novac, L. E., Badea, D. (2008), Supervision on the single European insurance market - interaction between regulation and competition, Analele Universităţii din Oradea - Seria Ştiinţe Economice, XVII (3), 410-414.

Sijben, J. J. (2002), Regulation versus market discipline in banking supervision: An overview - part 2, Journal of International Banking Regulation, 4, 55-71.

Wang, L. (2013), The Implications of Solvency II to Insurance Companies, Theses and Dissertations, Paper 480. 